\title{
Challenging Teachers' Pedagogic Practice and Assumptions about Social Media
}

\author{
Helen C. Cartner \& Julia L. Hallas \\ Auckland University of Technology
}

\begin{abstract}
This article describes an innovative approach to professional development designed to challenge teachers' pedagogic practice and assumptions about educational technologies such as social media. Developing effective technology-related professional development for teachers can be a challenge for institutions and facilitators who provide this support. To contend with this challenge, we drew on Bain's (2004) “baker's dozen” questions to guide the design of an online postgraduate course for teachers. This article discusses the design of the online course and what teachers came to understand about the relationship between social media and teaching as a result of completing the course activities. This small-scale case study utilised qualitative data from three cohorts of participating teachers and found that teachers do change their pedagogical practice and assumptions about social media for their own teaching contexts when they engage in course activities that challenge their existing mental models and encourage critical reasoning and reflection on learning.
\end{abstract}

Keywords: professional development, pedagogical practice, educational technologies, social media

Cartner, Helen C. \& Hallas, Julia L. (2017). Challenging teachers' pedagogic practice and assumptions about social media. Online Learning 21 (2) doi: 10.24059/olj.v21i2.1009

\section{Introduction}

This case study focuses on the design of a fully online, postgraduate course that supported teachers to challenge their pedagogical practice and assumptions about social media. It offers a fresh approach to the design of pedagogically focused, professional development courses for teachers who adopt social media for their own teaching contexts.

The global uptake of mobile devices such as smartphones, tablets, and laptops, synonymous with web 2.0 social media, has opened up new possibilities for learning and teaching in higher education and workplace learning contexts. As the impact of globalization continues to influence the growth of the knowledge-based society (Ball, 2013), graduates and 
employees who have technological skills and can think creatively are seen as integral to western economies (Bates \& Sangra, 2011; Bowen \& Guthrie, 2015). Accordingly, a growing number of studies call for teachers to engage in professional development activities that will support the integration of mobile devices and social media into their teaching practice (King \& Boyatt, 2015; Laurillard, 2014; Nicholas, Fletcher, \& Davis, 2013). Some studies, however, have found that technology-related professional development has not been successful (Bohle Carbonell, DaileyHebert, \& Gijselaers, 2013; Reid, 2014) with recent research focusing on two main issues. First, professional development interventions tend to be predominantly technologically focused rather than pedagogically focused (Kirkwood \& Price, 2013; Teras \& Herrington, 2014; Wilson, 2012) and second, teachers are unlikely to change their conceptions of teaching despite engaging in professional development activities (Owens, 2015; Rienties, Brouwer, \& Lygo-Baker, 2013).

This paper explains how Bain's (2004) baker's dozen questions were utilized to design an online course that took account of the professional development challenges described in the literature. We argue that the course activities guided participating teachers to question their current understanding of pedagogic practice through critical reasoning and reflection, and that this brought about conceptual changes in their attitudes about teaching with social media. This paper establishes the relationship between those course activities and teachers' interpretations of their own teaching contexts. The findings confirmed a link between the knowledge, skills, and attitudes teachers developed as a result of engaging with the course activities, and adjustments to their own teaching practice. The paper begins with a discussion of what we know about the impact of media on student learning, and then proceeds to consider the importance of designing pedagogically focused professional development within social constructivist principles. Next, we explain how Bain's (2004) baker's dozen questions guided the design of pedagogically focused course activities that challenged teachers' mental models and engaged them in critical reasoning and reflection on learning. The teachers who enrolled in the online course and took part in this study were in-service adult language, literacy, and numeracy (ALLN) teachers.

\section{Literature Review}

Few would argue that online technologies such as the Blackboard LMS and social media have improved access to education (Bates \& Sangra, 2011). However, decades of research have shown that media have had no significant impact on the effectiveness of student learning (Clark, 2001; Kirkwood \& Price, 2016; Oliver, 2013). Recent studies continue this trend. For example, in a study of iPad use in higher education, Nguyen, Barton and Nguyen (2015) found that iPads enhanced the learning experience of students but did not lead to improved learning outcomes. Cooper and Higgins (2015) found that they could not conclude that online instructional videos for undergraduate students improved learning and teaching. Tsekleves, Cosmas, and Aggoun (2016) examined the barriers to the use of serious games in higher education and concluded that it was unclear how games could be incorporated within formal education systems. Furthermore, researchers who undertook a second-order meta-analysis study summarizing 40 years of research concluded that their findings supported arguments by Clark (2001) that technology has little or no effect on student learning (Tamim, Bernard, Borokhovski, Abrami, \& Schmid, 2011). We align our views with Clark (2001), who has long argued that media itself do not influence learning, and that it is the instruction or pedagogy that makes the difference to students' learning. 
Research into the use of technology for teaching has indicated that teachers tend to focus on technology as the "means by which teaching happens," a technologically focused belief that technology "in and of itself” will improve student learning (Kirkwood \& Price, 2012, p. 4). This view is compounded by studies that focus on the affordances of social media. For example, blogs enable students to actively construct new knowledge by generating content, while wikis provide the opportunity for students to collaborate and thus, develop team skills (Mason \& Rennie, 2008). However, social media itself does not intrinsically motivate students to engage with it. Instead, it is the pedagogically focused activity created by the teacher that motivates students to use social media to complete the task. For example, in a study which examined the use of video assessment to enhance undergraduates' critical thinking, Walters, Hallas, Phelps and Ikeda (2015) found that students were not motivated to complete the assessment due to the video itself. Instead, these students perceived that while the video was fun to produce, they preferred the assessment to focus on developing an understanding of disciplinary concepts that they could apply in the workplace rather than on technical skills.

Contributing to this perspective that technology itself will improve student learning is the fact that professional development activities tend to emphasize the acquisition of technical skills, with less focus on challenging and developing teachers' pedagogical knowledge and conceptions of teaching, (Reid, 2014) or understanding the change in teacher roles (Minocha, Schroeder, \& Schneider, 2011). Instead, Ertmer andaOttenbreit-Leftwich (2013) argue that teacher professional development should "emphasise how, not what, technology should be used to achieve meaningful outcomes” (p. 175).

Kirkwood and Price (2013) offer a framework that clearly describes both pedagogically determined and technologically deterministic approaches to teaching and learning with technology. The framework demonstrates the "relationships between conceptions of teaching, approaches to teaching, and learning with technology” (p. 329). Kirkwood and Price argue that teachers who are pedagogically determined conceive of teaching from a learner-focused perspective, thereby taking an approach to teaching that develops the student. These teachers view themselves as the agent of change in addressing students' learning and consider how technology will be used by their students to achieve learning goals. Conversely, Kirkwood and Price suggest that teachers who are technologically deterministic conceive of teaching from a teacher-focused perspective and tend to take a transmission approach to teaching. In viewing technology as the agent of change, these teachers tend to replicate transmission-based practices with technology. Other researchers, such as Ertmer and Ottenbreit-Leftwich (2013), have also argued for professional development approaches that shift the focus from technological tools to the pedagogy used to support them. Additionally, numerous studies have suggested that a pedagogical focus can be achieved by combining the use of technology with social constructivist learning theory (Ally, 2008; Brinthaupt, Fisher, Gardner, Raffo, \& Woodard, 2011; Chen \& Bryer, 2012; Selwyn, 2011) and a student-focused approach to teaching (Ertmer \& OttenbreitLeftwich, 2013; Jonassen, Howland, Morre, \& Marra, 2003).

Social constructivist learning theory blends two perspectives: constructivism and social learning. Constructivist theory, developed from the work of psychologists Jean Piaget and Jerome Brunner, explains how people learn (Selwyn, 2011). The theory suggests that people learn by comparing new information to be learned with what they already know, thereby 
constructing a new understanding of the subject matter. New understanding occurs when students assimilate knowledge by modifying new information to fit with their existing knowledge (Gagon \& Collay, 2006; Selwyn, 2011). The social aspect of the theory was derived from Lev Vygotsky's work on social learning (Gagon \& Collay, 2006). A social learning approach assumes that students will find it less difficult to construct new knowledge when they are able to think through new concepts and problems in discussion with peers. The role of the teacher is to develop teaching strategies that require students to foreground and reflect on their current knowledge of, and previous experiences with, the concepts to be learned and then to actively engage students in processes based on inquiry and interpretation in order to make meaning (Selwyn, 2011). The application of this new knowledge to authentic or real life areas is a reflective process which helps to ensure that new knowledge has been understood (Horton, 2011). The next section describes how we interpreted Bain's (2004) baker's dozen questions to design pedagogically focused course activities that leveraged social media for ALLN teachers' professional development.

\section{Bain's (2004) Baker's Dozen Questions}

Teachers who wish to take a social constructivist approach to course design can facilitate the process by reflecting on a series of inquiry-based questions (Garrison \& Vaughan, 2008). For example, Bain's (2004) 13 questions (the “baker’s dozen”) represents one approach. The 13 questions are a result of a qualitative research investigation into 63 college-level teachers' perspectives on teaching. The teachers were nominated for the study mainly by students who suggested that they had made a significant difference to "their intellectual and personal development” (p. 182). According to Bain, these teachers developed strong reputations for supporting students' achievement, were highly regarded by colleagues, and were often major teaching award winners. The questions are the result of qualitative interviews with teachers that determined how they designed their courses with students' success in mind (Bain, 2004). Two examples of the questions are, "What mental models are students likely to bring with them that I will want them to challenge?" (p. 51) and "How will the students and I best understand the nature, progress, and quality of their learning?” (p. 60). The 13 questions have not been reproduced in this article; however Bain's (2004) book provides a detailed discussion of each of the questions along with examples of practice.

The baker's dozen questions comport strongly with social constructivist principles and provide a useful practical basis for course design. As such, the questions can act as a bridge between social constructivist theory and practice, supporting Kirkwood and Price's (2013) pedagogically focused approach to the use of social media for learning and teaching. The baker's dozen is underpinned by two key ideas: "that teaching is fostering learning and that it requires serious intellectual work” (Bain, 2004, p. 49). By reflecting on some or all of the questions, teachers are guided to design a course that focuses on fundamental concepts of learning and teaching. By perceiving patterns in the questions, we found that we could cluster 9 of the 13 questions under three specific fundamentals: challenging students' mental models, developing reasonsing skills, and reflecting on learning. Next, we discuss how these fundamental concepts align with the literature on developing a social constructivist approach to course design. 


\section{Challenging Learners' Mental Models}

Bain's questions 3, 6, and 13 focus teachers on challenging students' current mental models about the subject to be learned. To encourage such a conceptual shift, teachers should help students to identify their fundamental beliefs about a concept and then to challenge those assumptions (Bain, 2004). Bain argues that assumptions may be challenged by placing students in situations where their existing mental models are unlikely to work. For example, such a situation is likely to occur when teachers are given the opportunity to teach their peers in an unfamiliar online learning environment, causing their conceptions of teaching to be challenged. They will have to look inward to understand what "earlier beliefs" brought them to this "intellectual moment” (Bain, 2004, p. 54). If, in this moment, the process of conceptual change begins, it will continue, provided that teachers are required to examine the pedagogic evidence for the choices and actions they make (Shulman, 1986). By adopting a research-based approach as a result of such challenges, teachers will learn to draw on pedagogical reasoning to link teacher knowledge with teacher action (Trigwell \& Shale, 2004), thus beginning a reflective cycle of continuous improvement.

\section{Engaging in Critical Reasoning}

Questions 2, 4, 5, and 7 challenge teachers to think about how they might support students to critically reason about course content, skills, and attitudes. Bain (2004) argues that students are more likely to engage with course content if they are given the option to devise questions about their own life and work contexts. Giving students choices about what they learn and in a way that reflects how that knowledge will be used in their work and life is a key aspect of encouraging deep approaches to learning for adult students, and is underpinned by the principles of andragogy (Knowles, 1972) and authentic e-learning design (Herrington, Reeves, \& Oliver, 2010). As technology continues to disrupt the traditional view of learning and teaching and of teacher and student roles, teachers' assumptions about the use of technology should be challenged (Walker, 2002). Bain (2004, p. 51) argues that teachers should understand where students are likely to have difficulty "solving problems in the field," and that they should create a "sequence of experiences" that will encourage students to collaboratively practice and develop their critical reasoning skills. Affordances of social media that emphasise participatory, personal, and social learning (McLoughlin \& Lee, 2010, p. 28) may be leveraged to implement Bain's ideas as students take control of their learning through the creation and sharing of user-generated content (Allen \& Nelson, 2013; McLoughlin \& Lee, 2010; Waycott \& Sheard, 2011).

\section{Reflecting on learning.}

Questions 8, 9, and 12 encourage both teachers and students to understand a student's progress through the development of metacognitive strategies. When students engage in realworld inquiry utilizing social media to access information, they reduce their dependence on textbooks and teachers (Walker, 2002). Consequently, when teachers are no longer the source of all knowledge, their focus becomes the support of student learning. For example, taking steps to understand what individual students are learning or not learning enables the teacher to give feedback before an assessment process occurs (Bain, 2004). Additionally, helping "students to learn to learn, examine and assess their own learning and thinking” (Bain, 2004, p. 56) develops students' metacognitive abilities, which are part of a life-long learning skill set. In developing activities that direct students to reflect on the "nature, progress, and quality of their learning" (Bain, 2004, p. 60), both teacher and student gain a picture of what the student has come to 
understand. Correspondingly, for teachers engaged in professional development, reflection is relevant because it is a process that helps them to make connections about their own learning and to monitor patterns of change (Walker, 2002).

\section{Background}

We drew on Bain's baker's dozen questions to design a post-graduate course, and the course activities and assessment methods described in the following sections are the result. The Online Learning and Teaching course described in this paper was designed and taught by the authors of this article in a university in Auckland, Aotearoa New Zealand. It was designed as a fully online, postgraduate course for Adult Language, Literacy, and Numeracy (ALLN) teachers. Hereafter, participants taking this course are referred to as “teachers," while these teachers' own students are referred to as "students." The Online Learning and Teaching course was one of six in the Master of Adult Language, Literacy, and Numeracy program. Since the program began in 2004, social media and proficiency with these applications have been identified as essential to ALLN teachers' practice (Davis \& Fletcher, 2010). Consequently, the course was redesigned to reflect these developments and is described in the next section.

\section{Course Design and Course Activities}

The course design was framed by social constructivist learning theory, while Bain's (2004) baker's dozen questions were used to guide the design of the course activities. The course was conducted through the Blackboard LMS utilizing the wiki as the main learning and teaching space. One important aspect of the course design the limitation of required readings and resources posted in the LMS. As a result, teachers soon realized that they could co-construct the wiki pages for themselves, posting a variety of media resources which provided evidence of their developing arguments as they reasoned together. Another important aspect of the course design was to encourage participants to assume the role of the teacher. This occurred through content sharing and discussion, particularly in the wiki and during the optional weekly Blackboard Collaborate sessions. "Collaborate" is a Blackboard tool which provides real-time video conversation, enabling teachers to disclose new insights from their investigations and develop online facilitation skills by sharing the role of moderator. When teachers emulate the role of an online teacher (Laurillard, 2002) they take an active role in their own, as well as their peers', learning. Additionally, teachers were required to create an open access blog to document their learning and assessment outputs. Four major course activities were developed, with activities 2 and 4 also designed as assessment outputs, and these are discussed next.

Activity 1: Critique of the e-learning literature. For this activity, teachers were asked to develop a critical understanding of the research literature related to e-learning and ALLN education. To do this, teachers were asked to develop two researchable questions about learning and teaching with social media in their own teaching context, and to post these in the wiki. They were required to investigate their own question as well as a peer's question through a critical analysis of the literature, and to tap into educational blogs. The purpose of this activity was to encourage teachers to think like experts about online learning and social media within their discipline. The teachers chose to share the findings of their investigation in their personal blog (http://blogspot.co.nz) providing an avenue for critique and comment on each other's work. This 
activity provided much of the literature and subsequent ideas for blog posts which would contribute to activity 2 (assessment 1 ).

Activity 2 (assessment 1): Develop a philosophy of teaching and learning with technology. The teachers were asked to articulate a personal philosophy of technology-based teaching and learning. The purpose of this activity was to challenge teachers to examine their assumptions about how learning and teaching with technology occurs. To do this, teachers were first expected to investigate theories of online learning, and philosophies of technology in practice, with chapters by Ally (2008) and Kanuka (2008) as required reading. Second, teachers were asked to write a series of blog posts articulating their perspective on the use of social media for ALLN education and to provide evidence that would show how their approach to teaching and choice of social media would impact students' approaches to deep learning. The blog provided a platform for teachers to document their learning, communicate with their peers and with us, and to show conceptual change over time.

Activity 3: Reflections on learning. Teachers were invited to reflect on the course activities and assessments in order to explore how they experienced their learning, and to set goals for further learning. They used the Blackboard LMS anonymous survey tool to complete a selfreflection learning questionnaire during weeks 6 and 12 of the semester. The data gathered from the self-reflection questionnaires revealed teachers' subjective perspectives about how the course activities had developed their knowledge, skills, and attitudes about social media, and how their thinking about technology-related pedagogical practice had been changed or challenged. The self-reflection questions were adapted from Walker's (2002, p. 126) “cycle of reflection" questions that had originally been developed for teachers engaged in technology-related professional development. They provide teachers with a metacognitive tool to challenge their thinking and behaviors, supporting a cyclical process of change and improvement (Walker, 2002) which is a major aim of the post-graduate course. Walker's (2002) questions were adapted for activity 3 as follows:

1. What concepts and skills do I understand as a result of completing the course activities and assessments?

2. How has my thinking about social media for ALLN education been changed or challenged as a result of participating in the course activities and assessments?

3. What am I doing in my own teaching that relates to the course activities and assessments?

4. What am I learning in terms of my personal skills?

5. What goals should I set for the remainder of the course, or my own teaching?

This activity was designed to encourage teachers to reflect on what they had learned, the goals they would set next, and the implications for their own teaching contexts.

Activity 4 (assessment 2): Investigation of a social media tool. The final activity asked teachers to produce a "chapter" as a result of undertaking an in-depth evaluation of a social media tool appropriate for their own ALLN teaching context. The idea was that, once collated, each of the teachers' chapters would create an e-book for them to share and use as a resource. To do this, teachers selected a social media tool and provided a brief rationale for why it was worth investigating for ALLN education. Drawing on the work they had undertaken in activities 1, 2, and 3, they were expected to critically evaluate the tool for cultural and contextual 
appropriateness. Finally, they were required to develop a learning activity that utilized the tool, clearly demonstrating how it was designed to advance their students' ALLN education, and provide evidence to support the design. As with activity 1, activity 4 was designed to support teachers to use social media while engaging with the literature in order to collaboratively reason about the pedagogical implications of social media for their own teaching contexts.

Events. In addition to course activities, teachers were invited to take part in informal, voluntary events which lasted from a few hours to a couple of weeks at a time. The events were designed for teachers to trial tools that they would like to learn more about, such as Facebook and Twitter, in a stress-free and enjoyable way. A global online conference about social media in education occurred during one iteration of the course and became another voluntary event for teacher participation.

\section{Methodology}

A case study approach to inquiry (Stake, 1995) was undertaken for this research. The case study is congruent with research that seeks an in-depth examination of issues (Richards \& Morse, 2013; Stake, 1995) and has "the common goal of generating new ways of seeing existing data” (Richards \& Morse, 2013, p. 28). The goal of this research was to investigate whether teachers had engaged in deep learning as a result of completing the course activities. Therefore, instead of the usual satisfaction survey (using options such as "agree” and "disagree”) we chose qualitative, open-ended questions that facilitated and illuminated teachers' understanding of complex learning situations "that cannot be made explicit in most other research designs" (Barone, 2004, p. 25). Accordingly, this case study draws on the voices of the participating ALLN teachers to provide evidence of changes and challenges to their conceptions of teaching with, and assumptions about, social media for their own teaching contexts. The following sections outline the design of the study, the participants, and method of data analysis.

\section{Design of the Study}

This study drew on the qualitative data generated from two self-reflection questionnaires (Activity 3) undertaken in week 6 and week 12. The rationale for choosing these weeks was that, by week 6 , teachers had written a number of blog posts that demonstrated in-depth learning and had begun to formulate the teaching philosophy that framed their use of social media. The second questionnaire was posted at the end of the course in week 12. At this stage, teachers had completed the course activities and assessments and could provide further insights into how the course activities had challenged or changed their thinking about teaching and social media. The five questions which made up the survey tool were adapted from Walker's (2002) "cycle of reflection" questions. The data gathered for this paper comprise reflective responses to questions 1 and 2 only as these two questions provided the data most relevant to the topic of this paper. Data were collected via the Blackboard Learning Management System (LMS) anonymous survey tool.

\section{Participants}

The one-semester course was taught once each year over a three-year period. Altogether, three classes of teachers enrolled into the course between 2013 and 2015. They predominantly taught courses face-to-face with the intention of increasingly integrating social media strategies. 
The university's ethics committee granted approval for the study, and all teachers in the three classes were invited to participate. Twenty teachers volunteered to take part with only one teacher stating she did not agree to participate. Participants ranged from 34 to 67 years of age and were predominantly female.

\section{Data Analysis}

All the data from participant responses to questions one and two were downloaded from the Blackboard LMS, read and discussed by both researchers. The data were analysed using an inductive, thematic analysis approach and Stake's (2006) categorical aggregation method. This method involves gathering multiple instances of data that described the impact of the course activities on teachers' thinking. We examined responses for text that expressed teachers' perceptions that the course activities and assessments had triggered some impact on their thinking about teaching and social media. For example, Teacher 2 wrote: Especially through doing assessment 4, I have realised that we cannot just grab a teaching tool and use it (T2). This teacher clearly identified that she had constructed new knowledge about social media and teaching through the completion of assessment 4 and, therefore, her statement was coded and themed. Coding and theming occurred by identifying multiple instances of text, for example, where teachers had referred to the need for student-centred learning. In our initial analysis, we open-coded the data into themes such as the use of technology, advantages of different forms of social media e.g. blogs versus wikis, challenges to use of social media, and the impact of learning theories on participants' approaches to teaching. Teachers' responses were assigned to a theme. Subsequent reading and analysis of the data reduced to four the number of major themes discussed in the findings section. Accordingly, to manage the nature of qualitative research, a subjective method of analysis was required to make meaning from the complex data (Stake, 2006).

The next section of this paper reports the findings of the responses to the self-reflection questionnaires. It focuses on teachers' perspectives of how the course activities changed or challenged their knowledge of pedagogical practice in relation to social media. Anonymity has been ensured by assigning each teacher a number from 1 to 20.

\section{Findings}

Four key themes emerged from the analysis of data related to teachers' conceptions of social media for their own teaching contexts. They are: the constructivist model as a blueprint for designing learning; openness to the potential of social media; learner control; and a shift from worry to endless possibilities. The most common theme expressed by almost all of the participants related to the constructivist model. The importance of the learner in control was discussed by over half of the participants, while just under half referred to keeping an open mind and embracing endless possibilities. These themes are discussed next.

\section{A constructivist model for designing learning.}

A significant number of teachers commented specifically on the importance of constructivism as a learning theory. The teachers' comments indicated their beliefs that social media should be underpinned by a pedagogical design that would encourage students to construct their own knowledge: 
I believe it is about using a constructivist standpoint as a teacher, to allow students to construct knowledge as they go through the course. (T9)

I now understand concepts such as andragogy, constructivism and transformational learning. This self-directed learning where students construct their own knowledge and where dialogue plays an important role, allows me to understand how to go about designing course content as well as how to engage adult learners and make them feel comfortable, and develop a good relationship between us. The use of social media offers new possibilities for students. (T11)

The constructivist model of teaching and learning is a blueprint for the changing role of both teacher and student. The heightened acceleration of technological innovations in and out of the classroom has irrevocably changed the nature of education. The response to these changes demands a dramatic shift in the role and beliefs of teachers and the nature of learning for students. (T11)

These teachers perceived that courses which incorporated social media should be designed from a social constructivist approach in order to accommodate the required changes in learning and teaching. The teachers indicated that they had come to understand an important element of social constructivism: that students learn by constructing knowledge, and that this is facilitated dialogue, relationships, and self-directed learning. Additionally, there was a perception that the roles of the teacher and student had changed, and that teachers' beliefs about how students learn should be re-examined.

Teachers also perceived that the use of social media required a change in pedagogy that embraced social media as intrinsic rather than an "add-on” or to "jazz up” an existing paper. For example:

It should not just be an add-on to provide motivation or interest (although it may prove to be a motivating tool). The key question needs to be around how the integration of social media is enhancing the learning opportunities for learners. (T6)

We should eagerly embrace social media, but in a way that puts learning needs first. I realize how easy it is, if you are uninformed, to use new software/apps to jazz up a lesson without paying attention to the learning outcomes. I do think there is still a long way to go before we really come to grips with social media tools effectively. (T4)

Here, teachers described the importance of integrating social media into courses in order to facilitate goals such as outcomes that enhance what students learn. They were negative about the notion that adding a technology to a course would enhance learning, suggesting that such an approach would not achieve learning goals.

\section{Keeping an open mind to the potential of social media.}

Teachers indicated that they had become open-minded to the possibilities of social media. They suggested that they either made a conscious decision to be open-minded, or that the course 
activities prompted a change to a more open-minded approach. For some teachers, it was more an awakening to the potential of e-learning (T3), while for others it was a challenge at every turn (T4). Teachers made general comments that referred to all of the course activities, such as:

I have adopted a positive attitude of keeping an open mind towards new knowledge, new social media and re-evaluating the positive feedback that was and is given to me by my peers. (T10)

I have had an open mind to learn various applications/software/what educators have to say about social media teaching learning theories etc. (T3)

These teachers indicated that the course design encouraged them to examine their assumptions about social media and learning theories. Specifically, teacher 10 described a benefit of social constructivism, that is, how collaboration with peers can have a positive impact on one's learning. These teachers perceived that it was important to develop an open mind about the relationship between social media and teaching in order accommodate the changes required to change their beliefs.

Teachers also commented on specific social media tools they critiqued and used during the learning process, such as the blog, used for Activity 1 (Critique of eLearning literature). For example, writing the online blogs would have been something I would not have done without this course (T4) and creating my own blog has been an excellent experience and just through this I am hooked on social media (T3). Comments relating to Activity 4 (Investigation of a social media tool) indicated that teachers felt the need to consider the hows and whys of choosing digital tools (T6), and:

Especially through doing assessment 4, I have realised that we cannot just grab a teaching tool and use it. We need to know the potential challenges of using the tool and know how to use it in our teaching practice. (T2)

Teachers explained that they had learned about social media from two perspectives. First, they had learned how to use a blog to generate content and viewed this as an important learning experience. Second, having undertaken a critique of social media, they realised the importance of taking a pedagogical perspective when selecting and implementing tools for their own teaching practice.

\section{Learner in control.}

Teachers perceived that changing the role of the teacher had the potential to give students more control over their learning. This perception appeared to come from teachers' views of the design of the online course as well as the role modelling of the course facilitators. For example, the teachers perceived that the online course facilitators had acted as facilitators rather than as traditional teachers, giving them control to teach their peers themselves. For example: Teacher roles have often been reversed (T3).

Teachers observed that a richer learning environment may be developed when teacher and student roles are reversed, providing everyone with an opportunity to contribute their 
knowledge and experiences to the learning community: learning is more effective in a social context - the course has been designed to be very interactive (T3), and:

Another result of my learning has been that teachers work in different ways than previously. They are no longer the holder of knowledge; it is the Internet that does that now. That awareness is both freeing and scary. I see my own teaching will become more facilitating where I assist learners to negotiate the information they have access to (T17).

Here, teacher 17 is expressing the notion that the internet has become an additional way for students to acquire knowledge. Importantly however, teacher 17 understood that she must take control of this changing situation by developing a new pedagogical approach in order to accommodate the internet in her teaching practice. An interesting finding of this study was that each of the teachers referred to a student or learner-centred pedagogy with comments such as: keeping lessons learner-centred (T5), and I'm very much in favour of keeping lessons learnercentred (T6). Additionally:

Online learning fundamentally changes the role of the teacher and student. Online learning offers greater flexibility and self-determination to students, as they are able to take greater control of their learning and receive inputs from a range of sources, including other students, rather than being given one version of information by their teacher. (T10)

Teachers indicated that they held student-centred beliefs and, in doing so, perceived that online courses could be designed to enable students to access and utilise a range of resources, including peers, and give them the potential take greater control of their learning.

\section{From worry to endless possibilities.}

The majority of teachers used terms such as “challenge," “worry,” “anathema,” and "concern" to describe their feelings when they began the online course. Teachers' comments included: I was initially worried about how I could support my learners technically (T5), it is easy to feel overwhelmed and feel pressure (T6), social media when I joined this paper was anathema to me. The struggle was real for me (T16), and when I started this course I was totally lost (T9).

However, these initial responses changed to more positive outlooks, such as: but after a while I was totally hooked (T9), I have adopted a positive attitude (T19), I have now had a number of eureka moments (T12) or endless possibilities is how I sum up my thinking about learning and teaching with digital technologies (T9).

Teachers identified possibilities offered by social media that included viewing it as a thinking tool: social media is a powerful tool for developing abstract thinking potential in students (T20). Another teacher commented:

I believe the new dimensions of teaching and learning we can now access via digital technologies, create fundamental change in the way we think and reason which equips us to become life-long learners (T11). 
Here, teachers developed their own perceptions of how social media may benefit their students, and this opened a number of possibilities for their teaching practice. When considering their own literacy and numeracy teaching contexts, teachers expressed their understanding of the problems that their students may face when introduced to social media. In order to make full use of social media in their teaching practice, they explained:

It is important to understand the potential challenges of using social media and how to avoid the disadvantages (T2).

We need to reconsider the nature of online interactions... to set up the necessary level of digital culture - particularly in foundation students - this wasn't something I had thought about before (T5).

This final theme reflected changes in teachers' beliefs as they moved from their initial feelings of worry about social media at the start of the online course to feeling more confident towards the end of the online course. For example:

Learning how to create a blog has given me great confidence to use this tool and to integrate other social media into my literacy practice (T16).

My thinking was both changed and challenged as previously I'd viewed digital technologies as just other tools without realizing the opportunities for best practice that they offer. It has made me more interested in the possibilities it offers for education (T8).

Here, teachers perceived that by completing the course activities, they had become more confident in the use of social media, and that their thinking was both challenged and changed about educational technologies in general. Teacher 8 perceived that she had developed a bestpractice approach to educational technologies. Having developed new knowledge, skills, and confidence, it would appear that teachers were able to perceive that their future teaching practices would include educational technologies.

\section{Discussion}

This study found that using Bain's (2004) bakers’ dozen questions to guide the design of course activities and assessments was key to challenging and changing teachers' conceptions of teaching and assumptions about educational technologies, such as social media. The findings showed that these course activities and assessments supported teachers to focus on the investigation of the pedagogical aspects of educational technologies rather than on learning technical skills. Additionally, the findings indicated that the teachers developed Kirkwood and Price's (2013) perspective that they were the agents of change in their students' learning rather than the technology itself. The four findings - a constructivist model for designing learning; keeping an open mind to the potential of social media; learner in control, and from worry to endless possibilities - show strong relationships among the themes.

A constructivist model for designing learning. This finding showed that teachers viewed social constructivism as a blueprint for learning design. The literature suggests that, 
despite teachers adopting technology, they may resist changing their pedagogical approach (Newland \& Byles, 2014); however, this was not the case in this study. Instead, the teachers perceived that learning design should be underpinned by social constructivist learning theory. Gagnon and Collay (2006) argue that teachers have to undergo a conceptual shift in thinking about learning and teaching when developing a social constructivist approach. The teachers spoke of approaching teaching from a student-centred perspective when they considered what students would do during the learning process. They viewed social constructivism as enabling students to tap into their natural learning processes, by constructing knowledge and by selfdirecting their learning. This key theme of designing courses using a constructivist approach is supported by the literature (Kirkwood \& Price, 2013; Timperley, 2008) which asserts that, in order to change teacher's beliefs about social media, a shift from a technologically focused view to a pedagogically focused view is required. An indication that teachers had come to understand the importance of a pedagogically focused approach to teaching was heightened awareness about the integration of technology into a socially constructivist course design. Technology can be viewed by teachers as an "add-on" to a course or it can be used to motivate students (Mason \& Rennie, 2008), and this is a technology-as-agent-of-change perspective (Kirkwood \& Price, 2013). However, these teachers were adamant that technology should not be an "add-on," or used to "jazz up" a course. Instead, they spoke of social media as being integrated into the design of a course that is underpinned by social constructivism.

Keeping an open mind to the potential of social media. Teachers spoke of changing their attitude to become open-minded to the possibility of social media for teaching. They perceived that the course activities encouraged them to make a conscious decision to keep an open mind about the use of social media learning and teaching and towards the literature. Additionally, they viewed the experience of peer feedback on their blogs regarding their research as a positive turning point in understanding how social media worked. Therefore, the teachers perceived that the course design encouraged them to examine their assumptions about social media and associated learning theories. Becoming comfortable with uncertainty is a key aspect of challenging teachers' beliefs (Walker, 2002). The literature suggests that having an open mind is essential to any learning (Timperley, 2008) and carefully planned professional development can assist in breaking down barriers to technology adoption (Ertmer \& Ottenbreit-Leftwich, 2013). Similarly, Overbay, Patterson, Vasu, and Grable (2010) suggest that teachers should keep an open mind in order to see the potential for social media to support student development, including peer and tutor collaboration and opportunities to encourage higher-order thinking. This finding suggests that the course activities placed teachers in a position of uncertainty, thus challenging their existing mental models.

Learner in control. This finding showed that teachers came to understand that a course underpinned by social constructivism learning theory enables students to take control of their own learning processes rather than being directed by the teacher. Teachers appeared to have analysed the design of the online course and reflected on how the design affected their learning, for example, seeing the course as interactive and by observing how we facilitated learning and teaching online. In viewing the design of the course as encouraging interactive learning and social collaboration, they experienced how social constructivism works. They understood that in order for students to take control of learning, their role as teacher had to change and that, when technology was involved, they had to be the agents of change. In realising that they had to 
support students to deal with the content on the internet they recognised that their new role had to be guided by a teaching approach that would develop the learning of their students (Kirkwood \& Price, 2013). The course activities offered them the opportunity to experience how they could self-direct their learning. They investigated educational technologies for their own teaching contexts, and by using a blog to facilitate that research, they were able to see how it worked in practice, as well as the possibilities for how it might work for their own teaching context. These perspectives support Walker's (2002) conclusion that when teachers use technology for personal activities, they not only gain in confidence but may also make pedagogical changes to their role in the classroom. Additionally these viewpoints support the assertion that professional development is most effective when situated within a teacher's own teaching context (Dabner, Davis, \& Zaka, 2012).

Endless possibilities. This finding showed that teachers were thinking about teaching with educational technologies from a pedagogically focused perspective. They viewed themselves as agents of change in addressing their students' learning contexts, and they thought about how social media would be used by students to achieve their learning goals (Kirkwood \& Price, 2013). This was evident when teachers suggested that they had considered how to set up online interactions that would maximize the benefits of social media. They also considered how social media could change the way students think and reason, thereby facilitating an approach to lifelong learning. This finding demonstrated that throughout the online course, teachers developed the confidence to use social media and to take a student-centred approach for their own teaching contexts. It has been suggested that technology supports constructivist principles in a learning environment (Selwyn, 2011). The literature suggests that technology-enhanced learning is most effective when framed within a social constructivist approach whereby students are encouraged to learn with social media in order to generate their own content (Allen \& Nelson, 2013; Brinthaupt et al., 2011; Jones \& Harmon, 2011).

Technology-related professional development programmes that focus on technical skills are often seen as superficial and ineffective in changing teachers' conceptions of teaching (Kirkwood \& Price, 2013; Teras \& Herrington, 2014). This study has shown how two issues in the technology-related, professional development literature may be overcome. First, professional development should be intentionally designed to be pedagogically focused rather than technically focused. Second, the philosophy of a course and the design of its activities and assessments should be intentionally designed to challenge teachers' conceptions of teaching, through reasoning and reflection activities.

We argue that the design of effective online professional development courses may be guided by drawing on Bain's baker's dozen questions, while taking account of social constructivist learning theory and Kirkwood and Price's (2013) model of teaching with technology. We drew on this literature to design an online postgraduate course that would encourage teachers to investigate the effectiveness of educational technologies such as social media for their own teaching contexts. For us, the key to challenging teachers' conceptions about teaching and assumptions about educational technologies, was to use Bain's (2004) baker's dozen questions to guide the design of the course activities and assessments. We argue that these questions are vital to designing course activities that will challenge teachers' conceptions of teaching, engage them in reasoning about teaching and technology, and cause them to reflect on 
their learning. The baker's dozen questions reinforce social constructivist learning theory as the underpinning philosophy of courses that are designed to take account of how adult students learn. Additionally, we viewed our design and facilitation of the online course as pedagogically focused, as this perspective acknowledges that the teacher is the agent of change in learning and teaching contexts, and not the technology itself. Throughout the course, the teachers spent the majority of their time engaged in course activities that strengthened their pedagogical understanding of educational technology, with the technical aspects being minimised.

\section{Conclusion}

This study was motivated by studies which have argued that technology-related professional development is often technology focused rather than pedagogically focused, and that it has not been successful in changing teachers' conceptions of teaching. We argue that effective technology-related professional development can be achieved by using Bain's (2004) baker's dozen questions to guide the design of course activities and assessments. The findings from this study showed that teachers' views on pedagogic practice and assumptions about social media for teaching were influenced by the design of online course activities and assessments. As a result of completing the online course activities and assessments, teachers had developed a conception of teaching with technology that was pedagogically focused. Four concepts came across clearly in the findings. First, teachers viewed social constructivist theory as a blueprint for learning and teaching. Second, when considering how to integrate social media into their teaching contexts, they viewed themselves as the agents of change in their students' learning. Third, in recognising that the role of teacher and student changes within a social constructivist environment, they developed the perspective that students should be able to self-direct their learning. Finally, teachers developed a confident and positive vision of implementing educational technologies into their teaching practice.

This study was carried out with a small sample of cohorts in one post-graduate course within a single institution; therefore, it is not appropriate to attempt to generalize its findings to all such courses. However, this research could be carried further by undertaking post-course interviews to ascertain the participating teachers' use of social media in their current teaching practice. We argue that Bain's (2004) baker's dozen is an effective approach to the design of professional development programmes. Therefore, we recommend that further research be undertaken to investigate whether Bain's questions have similar implications for other technology-related professional development programmes. The findings from this study will be useful for course designers and teacher educators who wish to design courses with educational technologies, such as social media, and yet retain a pedagogical focus on learning and teaching.

\section{Acknowledgments}

We would like to acknowledge the support and encouragement in the final writing of this article provided by Dr. Elizabeth Turner, Dr. John Bitchener, and Dr. Nell Bussink. 


\section{References}

Allen, K., \& Nelson, D. (2013). A case study on integrating social media in an online graduate youth development course. MERLOT Journal of Online Learning and Teaching, 9, 566574.

Ally, M. (2008). Foundations of educational theory for online learning. Theory and Practice of Online Learning, 2, 15-44.

Bain, K. (2004). What the best college teachers do. Cambridge, MA: Harvard University Press.

Ball, S. J. (2013). The education debate (2nd ed.). Bristol, England: Policy Press.

Barone, D. M. (2004). Case-study research. Literacy Research Methodologies. 7-27.

Bates, A. W., \& Sangra, A. (2011). Managing technology in higher education: Strategies for transforming teaching and learning. San Francisco, CA: Jossey Bass.

Bohle Carbonell, K., Dailey-Hebert, A., \& Gijselaers, W. (2013). Unleashing the creative potential of faculty to create blended learning. The Internet and Higher Education, 18, 29-37. http://doi.org/10.1016/j.iheduc.2012.10.004

Bowen, W. G., \& Guthrie, K. M. (2015). Higher education in the digital age (updated ed.). Princeton, NJ: Princeton University Press.

Brinthaupt, T. M., Fisher, L. S., Gardner, J. G., Raffo, D. M., \& Woodard, J. B. (2011). What the best online teachers should do. Journal of Online Learning and Teaching, 7, 515-524.

Chen, B., \& Bryer, T. (2012). Investigating instructional strategies for using social media in formal and informal learning. The International Review of Research in Open and Distributed Learning, 13(1). Retrieved from http://www.irrodl.org/index.php/irrodl/article/view/1027/2073

Clark, R. E. (Ed.). (2001). Media are mere vehicles: The opening argument. In Learning from media. Arguments, analysis, and evidence. Connecticut: Information Age Publishing Inc.

Cooper, D., \& Higgins, S. (2015). The effectiveness of online instructional videos in the acquisition and demonstration of cognitive, affective and psychomotor rehabilitation skills: The effectiveness of online instructional videos. British Journal of Educational Technology, 46(4), 768-779. https://doi.org/10.1111/bjet.12166

Dabner, N., Davis, N., \& Zaka, P. (2012). Authentic project-based design of professional development for teachers studying online and blended teaching. Contemporary Issues in Technology and Teacher Education, 12(1). Retrieved from http://www.citejournal.org/vol12/iss1/currentpractice/article2.cfm 
Davis, N., \& Fletcher, J. (2010). E-learning for adult literacy, language and numeracy: A review of the literature. Wellington, New Zealand: Ministry of Education. Retrieved from http://thehub.superu.govt.nz/sites/default/files/41963_eLearningAdultLiteracy-7697115062010_0.pdf

Ertmer, P. A., \& Ottenbreit-Leftwich, A. (2013). Removing obstacles to the pedagogical changes required by Jonassen's vision of authentic technology-enabled learning. Computers \& Education, 64, 175-182. http://doi.org/10.1016/j.compedu.2012.10.008

Gagnon, G. W., \& Collay, M. (2006). Constructivist learning design: Key questions for teaching to standards. Thousand Oaks, CA: Corwin Press.

Garrison, D. R., \& Vaughan, N. D. (2008). Blended learning in higher education: Framework, principles, and guidelines (1st ed.). San Francisco, CA: Jossey-Bass.

Herrington, J., Reeves, T. C., \& Oliver, R. (2010). A guide to authentic e-Learning (1st ed.). New York, NY: Routledge.

Horton, W. (2011). e-Learning by design (2nd ed.). San Francisco, CA: Pfeiffer.

Jonassen, D., Howland, J., Morre, J., \& Marra, R. M. (2003). Learning to solve problems with technology: A constructivist perspective (2nd ed.). Columbus, $\mathrm{OH}$ : Pearson Education.

Jones, M. G., \& Harmon, S. W. (2011). The future of online learning in higher education. In D. Surry, R. Gray Jr \& J. Stefurak (Eds.), Technology integration in higher education: Social and organizational aspects (pp. 279-290). Hershey, PA: IGI Global. Retrieved from http://www.igi-global.com.ezproxy.aut.ac.nz/gateway/book/46987

Kanuka, H. (2008). Understanding e-learning technologies-in-practice through philosophies-inpractice. In T. Anderson (Ed.), The theory and practice of online learning (2nd ed., pp. 91-118). Edmonton, Canada: Athabasca University Press.

King, E., \& Boyatt, R. (2015). Exploring factors that influence adoption of e-learning within higher education: Factors that influence adoption of e-learning. British Journal of Educational Technology, 46, 1272-1280. http://doi.org/10.1111/bjet.12195

Kirkwood, A., \& Price, L. (2012). The influence upon design of differing conceptions of teaching and learning with technology. In A. D. Olofsson \& J. O. Lindberg (Eds.), Informed design of educational technologies in higher education: Enhanced learning and teaching (pp. 1-20). Hershey, PA: IGI Global. Retrieved from http://services.igiglobal.com/resolvedoi/resolve.aspx?doi=10.4018/978-1-61350-080-4

Kirkwood, A., \& Price, L. (2013). Missing: Evidence of a scholarly approach to teaching and learning with technology in higher education. Teaching in Higher Education, 18, 327337. http://doi.org/10.1080/13562517.2013.773419 
Kirkwood, A., \& Price, L. (2016). Technology-enabled learning implementation handbook. British Columbia, Canada: Commonwealth of Learning (COL). Retrieved from http://dspace.col.org/handle/11599/2363

Knowles, M. S. (1972). Innovations in teaching styles and approaches based upon adult learning. Journal of Education for Social Work, 8(2), 32-39.

Laurillard, D. (2002). Rethinking university teaching: A conversational framework for the effective use of learning technologies (2nd ed.). London, England: RoutledgeFalmer.

Laurillard, D. (2014). Thinking about blended learning: A paper for the thinkers in residence programme. Retrieved from http://www.kvab.be/denkersprogramma/files/DP_BlendedLearning_Thinking-about.pdf

Mason, R., \& Rennie, F. (2008). E-learning and social networking handbook: Resources for higher education. New York, NY: Routledge.

McLoughlin, C., \& Lee, M. J. (2010). Personalised and self-regulated learning in the Web 2.0 era: International exemplars of innovative pedagogy using social software. Australasian Journal of Educational Technology, 26(1), 28-43.

Minocha, S., Schroeder, A., \& Schneider, C. (2011). Role of the educator in social software initiatives in further and higher education: A conceptualisation and research agenda. British Journal of Educational Technology, 42, 889-903. http://doi.org/10.1111/j.14678535.2010.01131.x

Newland, B., \& Byles, L. (2014). Changing academic teaching with web 2.0 technologies. Innovations in Education and Teaching International, 51, 315-325. http://doi.org/ 10.1080/14703297.2013.796727

Nicholas, K., Fletcher, J., \& Davis, N. (2013). Using e-learning and digital technologies to overcome barriers for second-chance adult literacy learning. Journal of Teaching and Education, 2, 313-321.

Nguyen, L., Barton, S. M., \& Nguyen, L. T. (2015). iPads in higher education-Hype and hope: iPads in higher education-Hype and hope. British Journal of Educational Technology, 46(1), 190-203. https://doi.org/10.1111/bjet.12137

Oliver, M. (2013). Learning technology: Theorising the tools we study. British Journal of Educational Technology, 44(1), 31-43. https://doi.org/10.1111/j.14678535.2011.01283.x

Overbay, A., Patterson, A., Vasu, E., \& Grable, L. (2010). Constructivism and technology use: Findings from the IMPACTing leadership project. Educational Media International, 47, 1003-1120. http://doi.org/10.1080/09523987.2010.492675 
Owens, T. (2015). Practising what they preach? An investigation into the pedagogical beliefs and online teaching practices of National Teaching Fellows. International Journal for Academic Development, 20(1), 76-92. http://doi.org/10.1080/1360144X.2014.983112

Reid, P. (2014). Categories for barriers to adoption of instructional technologies. Education and Information Technologies, 19, 383-407. http://doi.org/10.1007/s10639-012-9222-z

Richards, L., \& Morse, J. M. (2013). Readme first for a user's guide to qualitative methods (3rd ed.). Thousand Oaks, CA: Sage.

Rienties, B., Brouwer, N., \& Lygo-Baker, S. (2013). The effects of online professional development on higher education teachers' beliefs and intentions towards learning facilitation and technology. Teaching and Teacher Education, 29, 122-131. http://doi.org/10.1016/j.tate.2012.09.002

Selwyn, N. (2011). Education and technology: Key issues and debates. New York, NY: Continuum International Publishing Group.

Shulman, L. S. (1986). Those who understand: Knowledge growth in teaching. American Educational Research Association, 15(2), 4-14.

Stake, R. E. (1995). The art of case study research. Thousand Oaks, CA: Sage.

Stake, R. E. (2006). Multiple case study analysis. New York, NY: The Guilford Press.

Tamim, R. M., Bernard, R. M., Borokhovski, E., Abrami, P. C., Schmid, R. F. (2011). What Forty Years of Research Says about the Impact of Technology on Learning: A SecondOrder Meta-Analysis and Validation Study. Review of Educational Research, 81(1), 428.

Teras, H., \& Herrington, J. (2014). Neither the frying pan nor the fire: In search of a balanced authentic e-learning design through an educational design research process. The International Review of Research in Open and Distributed Learning, 15, 232-253.

Timperley, H. (2008). Teacher professional learning and development (Educational Practices Series No. 18). Brussels, Belgium: The International Academy of Education. Retrieved from http://edu.aru.ac.th/childedu/images/PDF/benjamaporn/EdPractices_18.pdf

Trigwell, K., \& Shale, S. (2004). Student learning and the scholarship of university teaching. Studies in Higher Education, 29, 523-536. http://doi.org/10.1080/0307507042000236407

Tsekleves, E., Cosmas, J., \& Aggoun, A. (2016). Benefits, barriers and guideline recommendations for the implementation of serious games in education for stakeholders and policymakers: Serious games in education: guideline recommendations. British Journal of Educational Technology, 47(1), 164-183. https://doi.org/10.1111/bjet.12223 
Walker, R. (2002). A reflective cycle for teacher learning: The Christchurch ICT cluster project. In G. Hoban (Ed.), Teacher learning for educational change (pp. 115-142). Buckingham, England: Open University Press.

Walters, S. R., Hallas, J., Phelps, S., \& Ikeda, E. (2015). Enhancing the ability of students to engage with theoretical concepts through the Creation of learner-generated video assessment. Sport Management Education Journal (Human Kinetics), 9(2), 102-112. https://doi.org/http://dx.doi.org/10.1123/SMEJ.2014-0041

Waycott, J., \& Sheard, J. (2011). Editorial 27(5): Preface to the special issue - assessing students' Web 2.0 activities in higher education. Australasian Journal of Educational Technology, 27(5), iii-ix. https://doi.org/10.14742/ajet.929

Wilson, A. (2012). Effective professional development for e-learning: What do the managers think? British Journal of Educational Technology, 43, 892-900.

http://doi.org/10.1111/j.1467-8535.2011.01248.x 